DOI: $10.17951 / \operatorname{lrp} .2019 .38 .4 .77-95$

\title{
WiOLETTA KWIATKOWSKA
}

Uniwersytet Mikołaja Kopernika w Toruniu. Wydział Filozofii i Nauk Społecznych.

Instytut Nauk Pedagogicznych

ORCID - 0000-0001-8374-1370

\section{MaŁgorzata Skibińska}

Katedra Dydaktyki i Mediów

Wydział Filozofii i Nauk Społecznych

Uniwersytet Mikołaja Kopernika, Toruń

ORCID - 0000-0001-8972-7529

\section{ACTION RESEARCH AS A STRATEGY \\ TO DEVELOP UNDERGRADUATES' RESEARCH TOOL KIT IN THE LIGHT OF THEIR EXPERIENCE}

\begin{abstract}
The article presents the authors' reflections on the application of action research strategy in developing the research toolkit of undergraduates at the Nicolaus Copernicus University Faculty of Pedagogical Sciences. The research was based on students' opinions on conducting research using the action research strategy. Opinions were collected using semistructured interviews, which were recorded and transcribed. The study involved 16 students of pedagogy, participants of a proseminar and a diploma seminar. The students were preparing to work on their diploma theses and conduct a research process. The selected students elected to implement the action research strategy into their scientific activity. Data collected during the interviews attest to the usefulness of the adopted strategy which the respondents found helpful in solving educational issues in the examined communities. The undergraduates presented their opinions on action research, methods of identifying research problems, and the benefits of implementing action research in the course of scientific research activities. They also indicated difficulties in carrying out action research and stated research competencies recommended to equip future teachers with.
\end{abstract}

Keywords: action research, research tool kit, seminar, reflective practitioner 


\section{INTRODUTION}

The present study is a voice in the discussion on improving the research tool kit of future pedagogical staff by incorporating research methodologies focused on creating the knowledge needed for practice, which are an indispensable element of contemporary pedagogical reflection. Such reflective inference is based on knowledge closely related to practice. Its condition is to adopt an attitude of openness and to avoid routine or impulsive thinking and action. Thinking, as John Dewey, a precursor of reflective teaching, points out, consists in "reflecting on the possible impact of what is currently happening on what will happen, although it has not yet happened" (Dewey 1972, p. 202 in Paszenda 2017, p. 138). Dewey's views on the relationship between reflective experience and thinking in educational day-to-day reality were particularly close to Donald Schön, the creator of the concept of reflective practice based on acquiring professional knowledge in action and from experience, and not from the results of traditional empirical research. According to Schön, theoretical knowledge and scientific solutions are irrelevant in the face of real problems. Especially the dilemmas related to people are so unique, complex, and unstable that the methods of solving them based on scientific theorems are insufficient (Perkowska-Klejman 2011, p. 3).

The concept of reflective practice can be implemented by using a research approach based on action research methodology. This scientific method, although methodologically quite uniformly defined in the scientific literature, is still ambiguous in terms of nomenclature and semantics. Fifty years after Kurt Lewin disseminated the idea of action research - to check the effectiveness of scientific theories for a positive social change (Červinková 2012, p. 10) - and subsequent researchers further specified its framework (including Paulo Freire, Davydd Greenwood, Wilfred Carr, Teresa Hejnicka-Bezwińska, Maria Czerepaniak-Walczak, Hana Červinková, and Bogusława D. Gołębniak), research in action is still a general term for many activities aimed at supporting changes at the level of a group, organization or even society. Among the factors contributing to contemporary development of this research procedure are: 1) the crisis of scientific methods in social sciences, 2) the detachment of theory from practice, 3) and uncertainty resulting from rapid and continuous civilization and cultural changes minimizing the possibility of using generalizations of scientific theories in solving practical social problems.

Maria Czerepaniak-Walczak notes that action research has been recognized as an appropriate research paradigm in the field of education, since:

a) it is situational - it concerns diagnosing a problem in a specific context and attempting to solve it in that context; 
b) it requires a special type of participation - team members themselves conduct research directly or indirectly;

c) it is self-evaluative - modifications are constantly assessed in new situations, because the goal is to improve practice;

d) it is a collective effort - a team of researchers and practitioners (the same people are both researchers and practitioners) work together on the project (Czerepaniak-Walczak 2014, p. 184);

e) it uses triangulation whose essence is a multilateral analysis and interpretation of the studied area by combining three types of triangulation: theoretical (the use of many theories), methodological (the use of many methods, techniques and tools) and researchers (the participation of more than one researcher, a team conducting the study) (Czerepaniak-Walczak 2010, p. 333).

However, the most important feature of action research is the drive to combine theory with practice, action with reflection, and research with action and participation - this approach enables real reflective thinking leading to a change in the social and personal sphere.

\section{METHODOLOGY}

Proseminar and Diploma Seminar supervisors at the Faculty of Pedagogical Sciences of the Nicolaus Copernicus University in Torun in the academic year 2017/2018 and 2018/2019 were asked to expand their students' research toolkit by familiarizing and persuading the undergraduates to apply action research methodology in their research projects. Some lecturers and students faced a challenge of going beyond the traditional canon of diploma theses and focusing on their usefulness for educational practice. This proposal was also a response to the needs expressed by the students themselves, who wanted their research activities to be of social value, more meaningful, and momentous. During the proseminar, students read the literature on action research, developed a research plan, and identified pedagogically important research problems. They continued this extensive undertaking during their diploma seminar when they also implemented it. Student internships were helpful, because students could see existing problems and make initial diagnoses. Planning, implementing and writing a research report took the undergraduates and their supervisors at least 18 months of intensive work.

Empirical research was conducted individually by students in various educational and caregiving environments in the Kuyavian-Pomeranian Voivodeship. Discussion, analysis and reflection on the collected material took place during 
consultations at seminar meetings at the Faculty of Pedagogical Sciences of the Nicolaus Copernicus University in Torun. Students cooperated during seminar classes in five main phases:

1. conducting individual observations and collecting data on the functioning of selected educational and caregiving environments;

2. analyzing conclusions drawn from observations, contextualizing them theoretically and identifying problems;

3. planning and conducting activities aimed at implementing students' own pedagogical intervention;

4. analyzing the results of intervention, evaluating and deciding on the next steps in line with the action research framework (unfreeze - change - refreeze);

5. developing a research report.

Simultaneously to conducting research activities the students were also preparing the theoretical background for the subsequent chapters of their theses, and then defended the theses. Undergraduates were interviewed for the present study about their evaluation of the action research strategy they used. The semistructured interviews with 13 open-ended questions conducted from June to July 2019 were registered and transcribed.

16 students of pedagogy at the Nicolaus Copernicus University in Torun took part in the study. They became acquainted with literature devoted to action research during their proseminar and diploma seminars, and decided to implement this research strategy in their scientific activities.

The presented study adopted the following research problem: how do undergraduates of pedagogical studies perceive the action research strategy in their own research tool kit?

The main research problem has been used to identify the following categories of specific problems:

1. Understanding action research strategy. How do students understand action research strategy? How does action research differ from traditional research strategies according to the students?

2. Identifying the research problem. How did students identify research problems?

3. Difficulties in implementing a research project. What were the students' fears and difficulties during the implementation of the research projects? Was it difficult for students to create an intervention plan? What skills did the students lack during their work and implementation of their research project? 
4. Benefits of using action research in a research project. What results did the students want to achieve using action research? What benefits did the students see in carrying out action research?

5. Application of action research in teaching practice. Do students see the need to use action research in teaching and pedagogical practice?

6. Confrontation of own research activities with other people. Were students able to confront their actions and progress with others working on the project?

7. Tips for other people undertaking action research. What are students' recommendations for other young researchers implementing action research strategy?

Qualitative research was used to learn about the beliefs and opinions undergraduates had about the application of action research strategies more thoroughly, and thus understand the meanings that they attribute to this new experience.

Interviewees could share their observations based on their experience of implementing their research project, which may be significant for their choice to continue to apply action research strategies in subsequent projects of the diploma seminar, as well as in their future pedagogical work.

The collected statements present the young researchers' knowledge, competences and deficits in these areas, which may have implications for further work with students during the proseminar and diploma seminars.

\section{ANALYSIS OF AUTHORS' OWN RESEARCH}

The interviews began with the undergraduates being asked to explain the meaning of the term "action research". Students' answers indicate they see it as a strategy of social research, which requires understanding the phenomena and processes occurring in the existing reality and predicting their effects. They listed individual stages in the research activities, the involvement of all participants, and the usefulness of research leading to change. Some admitted that they were just experiencing and learning the role of a researcher. The following statements confirm the above findings:

Action research is aimed at improving the existing reality; it is practical, not just theoretical. The researcher not only studies, but also incorporates changes into life. In my opinion, action research brings out the researcher's emancipatory function (Agnieszka). 
Action research is about observing a problem that exists in a given environment. The researcher needs to prepare an intervention plan, carry it out, and then check whether the strategy works. If not, he needs to prepare and carry out the intervention plan once again (Marysia).

For me, these are certain actions that I take to change reality for the better - improve the current situation in a specific place. This is possible through the action and participation of the researcher in a given place (Joanna).

The respondents noticed the differences between action research and traditional research. They repeatedly emphasized their importance for educational practice, seeing them as an opportunity to change and engage both the researcher and the participants. They also pointed out that in action research, the distance between the researcher and the respondents is smaller, the researcher may be an amateur, and he/she has an impact on the course of the study. In a way, the researcher becomes a companion of the respondents in their everyday life. In contrast, in traditional studies the respondent does not influence the study and uses clearly defined research methods and instruments in a strictly defined time. Also, in the latter, the researcher has a precise research tool kit, unlike in action research with its fluent criteria of research correctness, an incomplete research process, sometimes limited only to non-reactive research.

In my opinion, the researcher is passive in traditional research. Here, we conduct an analysis, present the results and this problem is not solved - action research is a process where a real attempt is made to solve the problem and even to fully eliminate it. We can get results for educational practice and improve it. We rely on experience and observation (Dominika).

Action research, as the name implies, is based on action which requires our activity. Commonly, various studies are unfortunately most often shelved. After the initial admiration of the results and recognizing some facts nothing happens, except the reflection of the researcher or the person concerned. However, for research to make sense, its conclusions should be used in some way, so that they benefit a wider group of people affected by the problem. Action research is thus a kind of remedy for dusty shelves waiting for traditional studies. We hear so often today that researchers and scientists can only theorize. It's different here. The theory discovered by the researcher becomes the starting point for specific, further, real steps - for action. We cease to rely solely on words and turn them into action (Róża). 
The surveyed students demonstrated their knowledge of action research, which they gained during proseminar classes, where they become familiar with methodological literature on the topic. Students indicated that their research was usually undertaken on a small scale, referring to a specific situation in life. One person mentioned the emancipatory function of action research, because its main premise is to bring about change and improvement in practice. The researcher gets involved and attempts to intervene within the existing social group or with an individual. After collecting reliable data, the researcher analyses and interprets them to develop an intervention plan, which he/she then implements and assesses the obtained results. Several undergraduates also talked about subjectivity and active participation of the respondents, which is unheard of in traditional research.

The starting point for a research project is the formulation of research questions. It was also interesting to know how the respondents identified research problems and what helped them in this:

I think that literature was helpful in the first place. When I analyzed it, I had a preliminary idea of what I could study. My own experience was also crucial: I had people with DDA syndrome in my family, so that's why I found it interesting and I wanted to explore it myself. Certainly, my own experience mattered here (Iga).

First of all, observation. I have good contact with young people, I often meet with young people and I participate in their lives in a way, so I noticed that there is a problem with violence. This way I was able to identify the problem more easily. Daily observation (Anna).

During the September internship at school, apart from observing and teaching, I went to the common room, where I noticed that the children were glued to their mobile phones and the teachers were sitting at their desk, and I came up with the idea to study the impact of the media on children's development. I signed up for a volunteering program to deepen my knowledge and see exactly what the problem is about. And it was during the observations that I changed the research problem from the media to the animation of free time by using play. So, I noticed the problem I wanted to address thanks to these observations. If it were not for volunteering experience, I would not have chosen this field of research. As a result of being in the common room, spending time together, having fun, talking and observing what was happening to them, I could find it (Róża).

The respondents admitted that the need to formulate research questions resulted mainly from observations made in the local environment during student 
internships after exploring the given situation. Internship during studies, which - contrary to common belief - students may be interested in, enrich and inspire them to notice and then implement research projects. The research curiosity of the undergraduates also resulted from their knowledge broadened by reading scientific literature.

It was also important to determine what difficulties and fears accompanied the students when they conducted their research projects. The reported limitations included mainly difficulties in formulating research problems and observations correctly, interpreting results and drawing conclusions, and developing an intervention plan. Two respondents admitted that they lacked the necessary professional knowledge.

My biggest fear was probably the reaction of the studied environment to my initiative. I was afraid the kindergarten principal would disagree, or the teachers wouldn't support it. When it comes to other difficulties - finding the time to carefully plan and implement the changes. It was quite a long process, because it consisted of several stages: first the numerous meetings and conversations with teachers, many hours of analyzing kindergarten documentation, then the process of preparing scenarios, aids, and finally frequent meetings with children and rehearsals. Fortunately, teachers got involved and thanks to our efficient cooperation I was able to achieve my goals (Iga).

I didn't achieve my goals. I was afraid that I would have to start all over again. In action research we rely on action, so I have various possibilities to deal with the problem. It turned out that what scared me was exaggerated. I look at it differently now. I had doubts because I was doing it for the first time. But when I completed the study, I finally understood its meaning (Anna).

Defining research problems was the most difficult for me. I had to spend a lot of time making corrections. Then, after I transcribed the interviews, collecting, arranging and analyzing them required some solid work. I also see the need to continue this research strategy by implementing an intervention plan with teachers and pedagogues, organizing classes that could reduce this online violence and hate. I didn't do it for the lack of time, but it would be worthwhile (Marysia).

My fears concerned the teaching staff. When I went there, I had the impression that they were negative towards me. As if I were to take their jobs. Only one of the ladies was understanding, talked to me, and told me something more about the common room. She spoke about problems, that it is difficult to organize time with so many children around. She was the only person who helped me interact with these children, 
taught them to thank me for the attractive time. She taught them manners. In turn, the other ladies were very passive and only chatted with one another looking at the clock. The children did not know what to do on their own. The ladies only periodically silenced them so that they would not run around the room (Róża).

The above statements presenting the fears and feelings of the young researchers suggest that academic teachers should act to help students enter relationships, develop their communication, problem solving skills, and critical thinking. The undergraduates needed constant control and support from the seminar leaders to ultimately achieve the intended learning outcome: the students' understanding of the purpose and strategy of action research.

The respondents shared their insights referring to research assumptions. The research problems they undertook were extremely important to them. The students exhibited pedagogical sensitivity, commitment and faith in children.

You really need to be able to listen to these children to hear what they expect and know what we adults can offer them. Then they will follow us and engage in what we offer. Saying that children are bad, and you can't reach them is wrong. Everyone can be reached, but you need to give yourself. If we show initiative and engage in play, they will be even more willing and even suggest their ideas for play themselves. Without it, they do not know what they can do, what they are allowed to do, and what they are not allowed to do. I am an animator and I know various games. I wanted these ladies to see that the impossible is possible, if only we show ingenuity and commitment. I left them a list of materials and references (Róża).

The most important thing for me was to open adults' eyes: their children's lives revolve around the Internet, and even if parents claim that their children only visit secure sites, it may not be true. It seems to me that many adults are unaware of this. It is also important to make children realize what they do online does not remain in a vacuum. It can directly affect the other person they talk to, insult, call names. During my conversations with children, I noticed that it doesn't matter to them - they feel anonymous. It wasn't until I spoke to them that they began to realize that on the other side of the screen there is a person who may hurt, who is not a machine (Anna).

It was also interesting to know what the respondents thought they gained from implementing a research project using action research strategies. Their answers were:

I am now certainly more efficient in conducting interviews - conversations with another person, in this case a younger person who has a different view of the world, 
does not quite understand what is going on. In addition, I realized that these young teenagers are eager to talk to adults. They did not treat me as a person who would admonish them, they were pleased that someone would listen to them. They were glad that someone wanted to hear them out and their opinion is important. It is commonly believed that teenagers do not want to have anything to do with adults, that they have their own world, their lives and do not want to participate in the world of adults. When I talked to them, it turned out it was quite the opposite, that they feel appreciated when someone asks about their opinion, when someone does not judge them but allows them to speak (Agata).

I feel satisfied when I see happy children. I can't imagine children not knowing what to do in their free time. I see how important play is for their development. Thanks to it, we can develop large and small motor skills, practice mathematics in a way that is enjoyable for the child. I really enjoyed the effects of working with one boy, who at the beginning had huge problems with holding a pen, cutting, and throwing a ball. We practiced accurate ball throwing into cups until he succeeded and was pleased with himself. Bored children, after a week of playing with me, came to the common room smiling and laughing. For me it's a great satisfaction that children are happy and don't go home miserable or bored. I saw that my work is not irrelevant, and the children want to get involved and their energy can be used for good. If they are in a good mood and energetic, they are more willing to learn, and they learn more easily (Róża).

The students appreciated action research, because the results they obtained were meaningful and they could be relevant to the studied community. The undergraduates were satisfied with achieving change in the personal sphere (improved research toolkit, increased self-awareness and self-esteem) and the social sphere (improved quality of functioning of individuals and social groups in which they conducted their research activities).

While working on research projects, the respondents also admitted that thorough literature analysis, self-discipline and self-organization were necessary. They mention openness to themselves and others, understanding and confronting their own perspective with the existing ones.

I have found out that an in-depth analysis of the literature is necessary. It is not enough to read a few texts, you must do it thoroughly. It helps later in preparing the research project and determining whether what you assumed and implemented was accurate (Iga). 
First, that the researcher must be open to what others say to him. He cannot limit himself to his prejudices and assumptions, he must allow himself to learn something during the research that may change his view of the problem he is dealing with (Wiktoria).

I gained a lot thanks to the research project. I became more reflective. I learned to select information and evaluate my own work (Anna).

The undergraduates listed traits which researchers should possess and develop, which signals their own personal development and an increase in research and pedagogical awareness, necessary for effective cognitive activity in further studies and future professional work.

Respondents were also asked if they thought using action research by teachers and pedagogues was worthwhile. All agreed that applying this research strategy by practitioners (educators, caregivers) would be useful to solve problems.

I think so. Teachers encounter various problems every day. It wouldn't be normal to just ignore them and not try to solve them. I think teachers are unaware that they do that. In action research we have specific stages and it is easier to reach a solution. I think that this is a very useful way to learn about and deal with problems when working with people (Wiktoria).

Yes. The teacher should be a researcher who combines theory and practice to solve problems. The use of action research by teachers can facilitate their work, because all the stages in this strategy teach many necessary skills like assessment of one's own work (Joanna).

They could use such research in their practice. I think that it would make their work easier, because if they were discovering problems on a regular basis and looking at them more closely, they would be able to think and change quite quickly. If they would not succeed, they could try to deal with the problem again. For example, there may be problems with integration and exclusion in a group - it is worth finding the reason, observing children on a regular basis, getting to the heart of the problem and trying to solve it. I think it's an interesting solution (Róża).

The above statements confirm that action research is valuable in the field of educating educators, caregivers, and teachers. One of the results of research projects is a reflection on pedagogical tools and techniques. Students suggest that educators need to self-reflect, show commitment and strive to change in the area of their own pedagogical impact. 
Authors of the present study also wanted to find out what respondents think about the usefulness of action research. Data shows the most important aspects are: impact on the environment and significant changes that can occur.

I think that changing reality is important here. We often say that we do not like something in our lives or around us instead of acting, as is the case in action research. The ability to influence reality and the situation makes a difference here (Anna).

It allows you to change reality even on a small scale, so we can do a lot in your closest environment. I think that thanks to action research you can help others a lot (Dominika).

The usefulness of action research lies in the fact that it not only allows you to change something for the better, but also to test yourself as a researcher (Dagmara).

Even if we fail to complete all the stages, this end may again be the beginning of subsequent activities, something new. It teaches us to be reflective. In addition, it shows that often problems arising during the study may be more important and interesting than the assumed main research problem. What is more, the formula of action research allows us to see other issues that may be the cause of a given problem. Action research also fosters attitudes such as improvisation, perceptiveness and the ability to adapt to events. So, I think that this research formula fits into the dynamic and unpredictable world of a child perfectly (Róża).

The practical nature of action research is its greatest asset. The undertaken activities and their results are meaningful to the researcher, they build their selfesteem and sense of self-worth. The young researcher verifies the correctness of their own scientific reasoning and the effectiveness of the undertaken actions directly during and after the research. Thanks to cyclicality and triangulation of the research, they can correct their previous assumptions, methods, techniques and activities. The social utility of one's commitment strengthens the student's personal potential and increases motivation to plan further activities.

It was also important to determine whether it was difficult for the undergraduates to create an intervention plan. Both answers confirming the difficulties and suggesting lack of difficulties in this area can be found:

The biggest difficulty for me was developing this plan. I didn't know how to do it, where to start. I had an idea, but I couldn't describe it in such a way that I could use it (Dominika). 
No. It was something natural for me. I am an animator and playing with children is something I do every day. Preparation of the intervention plan was a natural consequence of my previous actions. At the beginning I knew that the task I had set for myself would not be so easy. On the first day, only a few children played with me, which I considered my success, because I was afraid that nobody would join in. This premonition appeared when I talked to one of the ladies working in the common room, who warned me about the reluctance of children to play. Fortunately, these fears were unfounded: each day more children played with me. After some time, the children started to initiate play. I can say that news of good fun in the school common room spread like wildfire among the kids (Róża).

Drafting an intervention plan was difficult for most students and required support from the seminar leaders and an in-depth analysis of scientific and professional literature. This stage, apart from analyzing the quality of functioning of the surveyed communities, required students to increase their intellectual effort and use their knowledge and skills. For this reason, the two moments in the research procedure: diagnosing problems and creating an intervention plan, require the greatest care in the process of educating future educators.

Another research problem was related to determining the type of skills that students lacked during their work on the research project.

Analyzing data and writing reports were my main shortcomings that I had to work on. While I could recognize the problem myself, specific skills were needed for the next stages. I managed to do it thanks to consultations with other people, notes from classes, literature and online sources (Dominika).

Certainly, action research was something new to me and I needed time to be able to observe a problem that was gradually emerging. Later, everything was much simpler. This beginning, how to go about it, what to do step by step - it was all difficult. Understanding the research problem was the most difficult. Literature was useful in the next stages (Róża).

The respondents admitted that they mainly struggled with writing the report. One of the undergraduates said that she had a problem in identifying (formulating) the research problem, and that literature on the subject proved useful.

While working on the project, students had the opportunity to confront their actions and progress with other seminar participants. They could count on each other if they had any doubts or problems. Only one person admitted that she inquired about the solutions to her research problem offered by other institutions. 
Yes. I collaborated with several people. If we had any questions, we would help each other out. If we had any doubts, we could rely on each other. Well, not with everyone. But the ones I keep in touch I could really count on (Iga).

We felt embarrassed at the beginning with this idea of action research, but I think it gave us a lot, because we could compare our experiences and conclusions. We had the opportunity to consult others about our problems many times (Victoria).

No, but I inquired what it looks like in common rooms in other cities. There are tutors and teachers in my family who are happy to share their experiences. In one school the common room is more of a "storage room for kids", while in another, as described in the literature, it has many functions: caregiving, recreational, and educational. Teachers try to learn about children's interests and help them spend this time actively and positively. Dance, art, crafts, and sewing classes are organized. There is even a corner where the child can calm down and relax (Róża).

It was also interesting to hear recommendations of the respondents for students of subsequent years who would conduct action research. The statements were lengthy, so it is impossible to present them all. The ones that contribute most to the present study are presented below:

There is an old proverb, "no pain, no gain" and I think that it suits action research perfectly. You can't be scared - stay calm, think, work and what you get will give you real satisfaction. See it as a new challenge that can reveal further interesting issues. If you want to develop and educate yourself then I think that this research strategy will bring you significant benefits. Media pedagogy is becoming a science facing a great challenge of understanding the world which is developing so rapidly, especially in the sphere of the broadly understood media. This is where we see numerous social problems studied by scientists and researchers. Theoretical polls and studies raise the alarm. Opening our eyes, we look with horror at the virtual world, many of us can no longer catch up with or are lost in. However, this alarm remains unnoticed. As if a team of firefighters learning about a forest fire remained passive in the face of a developing disaster. It takes practice. The researcher (theorist) observes the problem that affects him, describes it, draws up a report and informs others about it. When he notices that this problem affects himself and the surrounding reality, he decides to, or rather he has to use what he has learned to change the situation. The team of firemen sets out to put out the fire - the researcher takes action. An action from which he then draws conclusions, an action that saves the forest from burning down - which would have happened if the alarm was just noted down in a report tucked away on a dusty shelf (Dominika). 
The following statement of one student seems to be very accurate:

I think you need to begin your research before you can identify the problem. It is also worth getting involved in the research: do not approach the problem only from an external, objective point of view, but try to get close to the events. Of course, you should always keep in mind that you are there primarily as a researcher. The regularity of actions as well as consistency and inquisitiveness are also important. It seems to me that thanks to the above traits, every action research endeavor has a chance to be completed in full, using all possible and realistic means (Róża).

The respondents were willing to share their know how. During the interview their faces expressed surprise and delight when they realized their advice may be important and meaningful to others. They repeatedly emphasized the need to take action to implement a research project that is to end in an effective intervention in the studied educational reality leading to a change in its quality.

\section{DISCUSSION AND RESEARCH LIMITATIONS}

Action research results, in accordance with the research procedure, do not bring the researcher closer to knowing the "universal truth" since they refer to a specific group and its functioning. They report what members of a given community should do to achieve the desired change and they help the community to achieve it. Thus, they can become a source of valuable knowledge about solving problems and improving the quality of other local groups. In this sense, the results of this research procedure cannot be generalized because they are not fully usable outside the given environment.

The authors of this study are aware that this qualitative research with an unrepresentative sample makes it impossible to formulate generalizations and conduct reliable retests, however, the formulated observations and conclusions can be useful for educational theory and practice, with emphasis on the development of methodological skills of young researchers.

Referring to the previously formulated categories of research problems the following conclusions resulting from this research can be drawn.

With reference to the first category of research problems, understanding action research strategies, it was found that undergraduates who participated in the study understood action research (its essence, strategy, and methodological assumptions) after three terms of learning and experiencing this scientific method. They also noticed the differences between the applied research paradigms and indicated 
the benefits of implementing action research, even though they had been uneasy about it earlier, when they had not known it. In the second category of research problems regarding methods of identifying a research problem the collected material shows that most research problems were identified during participatory observation, when the respondents saw real problems of the local environment and irregularities disrupting the proper quality of its functioning. Moreover, the role and importance of student internships should be emphasized as they enabled students to become active participants in educational communities. Some respondents also sought confirmation or justification of the identified problems in the scientific literature, which aligns with the action research methodology.

Within the category of research problems related to the difficulties associated with the implementation of a research project (i.e. diagnosing problems, formulating research problems, construing an intervention plan and writing a research report) there is a need to focus on presenting specific examples of already implemented action research projects, including the methodology for developing the research report. The above postulate will be implemented in future editions of the seminar classes.

Another category of research problem was a group of questions about the benefits of using action research working on a research project. Data suggest that research carried out by the respondents awoke their greater research awareness, pedagogical sensitivity, diagnostic skills, and causative opportunities to make a difference in the studied communities. Thus, it can be assumed that there has been an increase in their self-esteem.

The next group of research questions referred to the possibility of using action research in teaching practice. According to the respondents, action research is valuable and useful in teaching practice. The advantages of implementing this scientific method, indicated by the students, lie in that it makes teachers self-reflect, engage in their teaching practice, and revise their teaching activities; all this can bring about appropriate and timely changes in specific educational environments, according to the respondents.

Another category of problems dealt with the question of confronting one's own research activities with other people - the present study showed that cooperation between undergraduates and their supervisor, and among the undergraduates themselves is helpful - it allows them to make decisions together regarding methodological correctness and inspire one another.

The last category of research problems refers to advice given to other action research practitioners. Students willingly shared tips resulting from their research experience. One of their suggestions was to be open to the new and the unknown. They indicated the need to look without routine, prejudices and fears at themselves and the studied community. They stressed the importance of developing 
self-discipline, proper commitment and preparation for the research, preparing the necessary documentation and thoroughly analyzing and interpreting the observed processes and phenomena. They also called for patience in dealing with difficulties related to carrying out research activities, e.g. if your interventions fail, use your conclusions to implement the next stages of your action research cycle.

Despite the undergraduates' earlier concerns regarding the use of action research strategy, they all carried out appropriate actions enabling them to carry out the research. Among the most common difficulties were the issues of skillfully diagnosing problems, formulating research problems, creating an intervention plan and writing a research report. These skills require more attention from the seminar supervisors so that the students can practice them in class. Students should also be encouraged to continue their activities, especially in situations where their intervention was unsuccessful. All difficulties and doubts dispelled by lecturers contributed to developing students' knowledge.

\section{CONCLUSIONS}

Scientific cognition has become the subject of Jürgen Habermas' interest, recognizing human interests, arising from the problems people experience and the needs they feel, as factors organizing knowledge production processes and human cognitive activity. He lists three types of such interests constituting cognition: technical, practical and emancipatory, assigning a specific type of knowledge and area of science to each of them (see Dziemianowicz-Bąk 2010, p. 11). The technical interest is typical for natural and social sciences - analytical and empirical in nature, whose theoretical basis were positivism, pragmatism and their derivatives. Knowledge is the effect of sensual cognition, subjected to objectification and verification, and its effect is to control and manage the studied reality. Practical interest is attributed to the humanities and interpretive sciences. It is focused on protecting and expanding the "intersubjectivity of possible, action-oriented mutual understanding" (Habermas, 1985, p. 164), in which reality can only then be revealed. In turn, the emancipatory interest is associated with a new type of human knowledge of a communicative nature oriented at social action. The determinant of this knowledge is self-reflection and the primary principle of striving for maturity and autonomy (Milerski 2015, pp. 44-45).

Maria Czerepaniak-Walczak claims that the three interests may be implemented in in action research:

a) technical interest - research conducted in this paradigm allows researchers to achieve goals such as: improving practice and improving the situations 
in which the practice takes place by attempting to explain and control the described educational reality;

b) practical interest - the purpose of action research is to increase understanding of the practice and mechanisms governing it through mutual interpretations of the world in the course of social interactions leading to the discovery of norms and meanings that exist in objective reality;

c) emancipatory interest - the purpose of action research in this paradigm is to understand and participate in achieving new rights and areas of subjective freedom (see Czerepaniak-Walczak, 2014, p. 188); action results in personal knowledge, whose source is self-reflection.

The use of action research methodology does not discredit scientific knowledge but appreciates the possibility of realizing the practical and emancipatory interest in the personal and professional development of future researchers. It helps them understand the possibility of using the results of scientific research carried out in accordance with the positivistic research paradigm - creating knowledge that is reliable, objective, free from valuation, and based on sensory cognition and empirical measurement. At the same time, it gives the researcher a sense of agency and usefulness of the research process. That is why it is worth including action research strategy in the toolkit of scientific methods used by teachers and pedagogical students to enable them to become reflective practitioners.

\section{REFERENCES}

Červinková H., 2012, Badania w działaniu i zaangażowana antropologia edukacyjna. „Teraźniejszość - Człowiek - Edukacja”, 1(57), 7-18.

Czerepaniak-Walczak M., 2010, Badanie $w$ działaniu. W: S. Palka (red)., Podstawy metodologii badań w pedagogice. Gdańsk, GWP, 319-337.

Czerepaniak-Walczak M., 2014, Badanie w działaniu w kształceniu i doskonaleniu nauczycieli. „Przegląd Badań Edukacyjnych”, nr 19 (2/2014), 181-194. DOI: 10.12775/ PBE.2014.028.

Dewey J., 1972, Demokracja i wychowanie. Wprowadzenie do filozofii wychowania. Wrocław, Zakład Narodowy im. Ossolińskich.

Dziemianowicz-Bąk A., 2010, Interesy konstytuujące nauczanie. W: M. Syska (red.), Komercjalizacja edukacji - konsekwencje i nowe zagrożenia. Warszawa-Wrocław, Wyd. OMS im. F. Lassalle'a, 11-21.

Habermas J., 1985, Interesy konstytuujace poznanie. „Colloquia Communia”, nr 2, 157-169. Milerski B., 2015, Racjonalność kształcenia szkolnego jako kategoria pedagogiczna. „Studia z Teorii Wychowania”, 6(1), 33-51. 
Paszenda I., 2017, Doświadczenie refleksyjne w codzienności edukacyjnej - spojrzenie pragmatystyczne. Wrocław, Instytut Pedagogiki Uniwersytetu Wrocławskiego [pozyskano z: http://repozytorium.uni.wroc.pl/Content/89343/10_Paszenda_Iwona_ Doswiadczenie_refleksyjne_w_codziennosci_edukacyjnej.pdf [dostęp: 25.06.2019].

Perkowska-Klejman A., 2011, Refleksyjna praktyka jako kategoria edukacyjna. „Pedagogika Społeczna” 2(40) Rok X 2011, 61-77 [pozyskano z: https://www.researchgate. net/publication/316739967_Refleksyjna_praktyka_jako_kategoria_edukacyjna [dostęp: 26.06.2019]. 